УДК 338.486: 483.1(485)

https://doi.org/10.35546/kntu2078-4481.2021.3.25

К.В. ТРУХАЧОВА

Херсонський національний технічний університет ORCID: 0000-0001-7223-8067

Н.А. ВЛАСЕНКО

Херсонський національний технічний університет ORCID: 0000-0003-4137-6357

О.С БИЛИМ

Херсонський національний технічний університет ORCID: 0000-0003-0102-4058

М.О. ШУЛЬГА

Херсонський національний технічний університет

А.С. ПЕРЕЛИГІНА

Херсонський національний технічний університет

\title{
РЕАЛІЗАЦІЯ ЗАВДАННЬ ЛОГІСТИКИ РЕСУРСНОЇ БАЗИ ТУРИЗМУ В КЛЮЧІ ТЕНДЕНЦЙ РОЗВИТКУ ПОВЕДІНКИ СПОЖИВАЧА, АСПЕКТИ: ЕКОЛОГІЗАЦІї, ВАЛЕОЛОГЇ̈, КУРОРТОЛОГІї ТА АНІМАЦІї
}

У даній прачі докладно розглянуті ключові завдання логістики ресурсної бази туризму й можливості їх реалізації з позицій екологізації, валеологї, курортологї та анімації з урахуванням тенденцій розвитку поведінки споживача туристичного продукту/послуги.

Доведено необхідність впровадження концепиіі логістичного підходу до управління на підприємствах за для досягнення $і$ утримання свої конкурентних переваг в туристичному бізнесі. Відмічено, щзо прочес впровадження логістичного підходу до управління в туристичному бізнесі не суперечить внутрішній соціально-економічній політиці туристичного підприємства і не тягне за собою кардинальних нововведень. Даний підхід лише доповнює ї̈, виводячи, як окреме підприємство, так $і$ всю систему туристичного бізнесу на більш високий рівень розвитку, що забезпечує поліпшення економічного, ресурсного, екологічного стану територій та краӥни.

Встановлено, щзо логістика ресурсної бази є компонентом системи управління в туристичному бізнесі, яка містить функиіональні області і вирішує певні завдання пов'язані: із визначенням значення ресурсної бази для бізнесу і споживача; раціональним використанням туристичних ресурсів та логістичною оцінкою потенціалу й науково-методичною реалізацією логістичного підходу до управління ресурсами туризму. Визначено місие логістики ресурсної бази у системі управління в туристичному бізнесі.

3'ясовано наступне: логістична оцінка рекреачійних туристичних ресурсів базується на визначенні їх логістичного потенціалу, тобто максимально можливої для даного туристичного ресурсу кількості споживачів (потік туристів); в сучасній науковій літературі існує чотири підходи до методики визначення логістичного потенціалу ресурсної бази туризму. Окреслено сутність й значення туристичних ресурсів для бізнесу і споживача, виділено три їх категорії та два класи.

Досліджено питання раціонального використання туристичних ресурсів, з позицій екологізації, валеології, курортології та анімації з урахуванням тенденцій розвитку споживача туристичного продукту/послуги. Виділено суб'єктивні категорії екологічного усвідомлення в значенні раціонального використання ресурсної бази туризму. Виокремлено: детермінанти формування «здорового стилю життя» у суб'єктивній системі життєздатності - «Трикутник особистості»; умови та фактори формування «здорового стилю життя», як поведінки споживача рекреаційних туристичних ресурсів. Дістало подальшого розвитку поняття «здорового стилю життя» та конщепщія валеотурізму.

Ключові слова: туристична логістика, туристичні ресурси, туристичний бізнес, тенденції розвитку поведінки споживача, екологізачія, валеологія, курортологія, анімація.

Е.В. ТРУХАЧЁВА

Херсонский национальный технический университет ORCID: 0000-0001-7223-8067

Н.А. ВЛАСЕНКО

Херсонский национальный технический университет ORCID: 0000-0003-4137-6357

Е.С БЫЛЫМ

Херсонский национальный технический университет ORCID: 0000-0003-0102-4058 


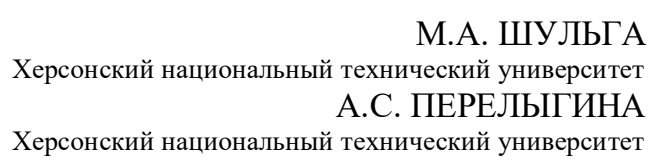

\section{РЕАЛИЗАЦИЯ ЗАДАЧ ЛОГИСТИКИ РЕСУРСНОЙ БАЗЫ ТУРИЗМА В КЛЮЧЕ ТЕНДЕНЦИЙ РАЗВИТИЯ ПОВЕДЕНИЯ ПОТРЕБИТЕЛЯ, АСПЕКТЫ: ЭКОЛОГИЗАЦИИ, ВАЛЕОЛОГИИ, КУРОРТОЛОГИИ И АНИМАЦИИ}

В данной работе подробно рассмотрены ключевые задачи логистики ресурсной базы туризма и возможности их реализации с позищий экологизаџии, валеологии, курортологии и анимации с учетом тенденций развития поведения потребителя туристического продукта / услуги.

Доказана необходимость внедрения кониепщии логистического подхода к управлению на предприятиях для достижения и удержания своих конкурентных преимуществ в туристическом бизнесе. Отмечено, что прочесс внедрения логистического подхода к управлению в туристическом бизнесе не противоречит внутренней социально-экономической политике туристического предприятия и не влечет за собой кардинальных нововведений. Данный подход лишь дополняет ее, выводя, как отдельное предприятие, так и всю систему туристического бизнеса на более высокий уровень развития, обеспечивает улучшение экономического, ресурсного, экологического состояния территорий и страны.

Установлено, что логистика ресурсной базы является компонентом системы управления 6 туристическом бизнесе, которая содержит функииональные области и решает определенные задачи связанные с: установлением значением ресурсной базы для бизнеса и потребителя; рациональным использованием туристических ресурсов; логистической оченкой потенциала и научно-методической реализацией логистического подхода к управлению ресурсами туризма. Определено место логистики ресурсной базы в системе управления туристического бизнеса.

Выяснено следующее: логистическая оценка рекреационных туристических ресурсов базируется на определении их логистического потенциала, то есть максимально возможной для данного туристического ресурса количества потребителей (поток туристов); в современной научной литературе существуют четыре подхода $к$ методике определения логистического потенщиала ресурсной базы туризма. Обусловлены сущность и значение туристических ресурсов для бизнеса и потребителя, выделены три их категории и два класса.

Исследован вопрос рационального использования туристических ресурсов, с позиций экологизации, валеологии, курортологии и анимаиии с учетом тенденций развития потребителя туристического продукта / услуги. Выделены субъективные категории экологического сознания в смысле рационального использования ресурсной базы туризма. Выделены: детерминанты формирования «здорового стиля жизни» в субъективной системе жизнеспособности - «Треугольник личности»; условия и факторы формирования «здорового стиля жизни», как поведения потребителя рекреационных туристических ресурсов. Получило дальнейшее развитие понятие «здорового образа жизни» и кониепция валеотуризма.

Ключевые слова: туристическая логистика, туристические ресурсы, туристический бизнес, тенденции развития поведения потребителя, экологизаџия, валеология, курортология, анимация.

K.V. TRUKHACHOVA Kherson National Technical University ORCID: 0000-0001-7223-8067

N.A. VLASENKO

Kherson National Technical University ORCID: 0000-0003-4137-6357

O.S. BYLYM

Kherson National Technical University ORCID: 0000-0003-0102-4058

M.A. SHULGA

Kherson National Technical University A.S. PERELYGINA

Kherson National Technical University

IMPLEMENTATION OF TASKS FOR LOGISTICS TO THE RESOURCE BASE ON TOURISM IN THE KEY OF DEVELOPMENT TRENDS IN THE DIRECTION OF CONSUMER BEHAVIOR, ASPECTS: ECOLOGIZATION, VALEOLOGY, SPA TREATMENT AND ANIMATION 
This paper discusses in detail the key tasks of logistics on the resource base of tourism and the possibilities of their implementation from the standpoint of greening, valeology, SPA treatment and animation, taking into account the trends in the development of consumer behavior of a tourist product / service.

The necessity of introducing the concept of a logistic approach to enterprise management in order to achieve and maintain their competitive advantages in the tourism business has been proved. It is noted that the process of introducing a logistic approach to management in the tourism business does not contradict the internal socio-economic policy of a tourism enterprise and does not entail cardinal innovations. This approach only complements it, bringing both an individual enterprise and the entire tourism business system to a higher level of development, provides an improvement in the economic, resource, ecological state of the territories and the country.

It has been established that the logistics of the resource base is a component of the management system in the tourism business, which contains functional areas and solves certain problems associated with: establishing the value of the resource base for business and consumers; rational use of tourist resources; logistic assessment of potential and scientific and methodological implementation of a logistic approach to tourism resource management. The place of logistics of the resource base in the management system of the tourism business has been determined.

The following was found out: the logistic assessment of recreational tourist resources is based on the determination of their logistic potential, that is, the maximum possible number of consumers for a given tourist resource (tourist flow); in modern scientific literature, there are four approaches to the methodology for determining the logistics potential of the resource base of tourism. The essence and significance of tourist resources for business and consumers are determined, their three categories and two classes are identified.

The issue of rational use of tourist resources is investigated from the standpoint of ecologization, valeology, SPA treatment and animation, taking into account the development trends of the consumer of the tourist product / service. The subjective categories of ecological consciousness in the sense of the rational use of the resource base of tourism are highlighted. Highlighted: determinants of the formation of a "healthy lifestyle" in the subjective system of vitality - "personality triangle"; conditions and factors for the formation of a "healthy lifestyle" as the behavior of a consumer of recreational tourism resources. The concept of "healthy lifestyle" and the concept of valetourism were further developed.

Key words: tourism logistics, tourism resources, tourism business, trends in the development of consumer behavior, greening, valeology, SPA treatment, animation.

\section{Постановка проблеми}

На тлі сучасної будови світогосподарських взаємовідносин характерним є функціонування різних міжгалузевих комплексів. Відтак, до туризму слід підходити як до міжгалузевого господарського комплексу національної економіки, що проявляє свою сутність через сукупність взаємопов'язаних галузей і виробництв з'єднаних функціональним завданням задоволення різноманітних і постійно зростаючих потреб людини в різних видах відпочинку, оздоровлення та подорожей при раціональному використанні всіх наявних туристичних ресурсів через взаємодію із довкіллям. За для перспективи свого виживання в складній конкурентній боротьбі у туристичному бізнесі також існують різні підприємницькі колаборації. Дані об'єднання сприяють забезпеченню одних і тих же технологічних, організаційних та економічних умов господарської діяльності підприємств як єдиного цілого у формі туристичних логістичних систем.

Аналіз останніх досліджень і публікацій

Проблематикою логістики туризму на мезорівні, його сталого розвитку й логістики ресурсної бази туризму в українському науковому просторі займається Смирнов І.Г. Питання модернізації логістичної системи в туристичних фірмах висвітлені у Лукіна А.М. Перспективи застосування логістичного підходу в управлінні туристичною діяльністю знайшли відгук у працях Григана С.А. Методи оцінки пляжних ресурсів, рекреаційних територій та інноваційного потенціалу бальнеологічної курортної території знайшли своє відображення у працях Гришина І.Ю., Данильчука В.Ф. та Донченко Л.М. Однак поглибленого вивчення питань пов'язаних з акцентуванням та докладним опрацюванням ключових завдань логістики ресурсної бази туризму саме з позицій екологізації, валеології, курортології та анімації ще не було проведено, що й зумовило мету даного наукового дослідження.

\section{Формулювання мети дослідження}

Метою даної праці $є$ виділення ключових завдань логістики ресурсної бази туризму та їх докладне опрацювання 3 позицій екологізації, валеології, курортології та анімації з урахуванням тенденцій розвитку споживача туристичного продукту/послуги.

\section{Викладення основного матеріалу дослідження}

У зв'язку з розвитком технологічних інновацій і глобалізацією туристичного бізнесу, підприємства, для досягнення і утримання своїх конкурентних переваг, повинні обов'язково враховувати логістичний підхід до управління в туристичному бізнесі. Концепція логістичного підходу до 
управління в туристичному бізнесі дозволяє значно підвищити його прибутковість за рахунок скорочення витрат та підвищення рівня логістичної координації всіх операцій з обслуговування туристів [15].

Отже, система управління в туристичному бізнесі, яка застосовує логістичний підхід - це система, що базується на компліментарному підході, що дозволить створити реальну можливість об’єднання функціональних областей логістики шляхом координації дій, виконуваних незалежними ланками логістичної системи, які поділяють спільну відповідальність в рамках цільової функції управління туристичними підприємствами [7]. Міжгалузева і внутрішньогалузева взаємодія дає можливість підприємствам спільно розподіляти та використовувати ресурсну базу туризму.

Треба відмітити, що процес впровадження логістичного підходу до управління в туристичному бізнесі не суперечить внутрішній соціально-економічній політиці туристичного підприємства і не тягне за собою кардинальних нововведень, а лише доповнює іiі, виводячи, як окреме підприємство, так і всю систему туристичного бізнесу на більш високий рівень розвитку, що забезпечує поліпшення економічного, ресурсного, екологічного стану територій та країни.

Отже, туристична логістика грає консолідуючу роль, об'єднуючи логістичні ланки в єдину логістичну систему весь туристичний бізнес, змінюючи менеджмент, маркетинг та організаційну поведінку від загальноприйнятого - ефективного функціонування до сучасного - результативного. А логістика ресурсної бази з точки зору туризму - це наука про планування, здійснення контролю i менеджмент операцій, а також процес передачі, зберігання і обробки інформації щодо туристичних ресурсів в процесі розробки туристичного продукту, доведення кінцевої послуги/продукту до споживача відповідно його інтересам [11]. Місце логістики ресурсної бази у системі управління в туристичному бізнесі показано на рис. 1 .

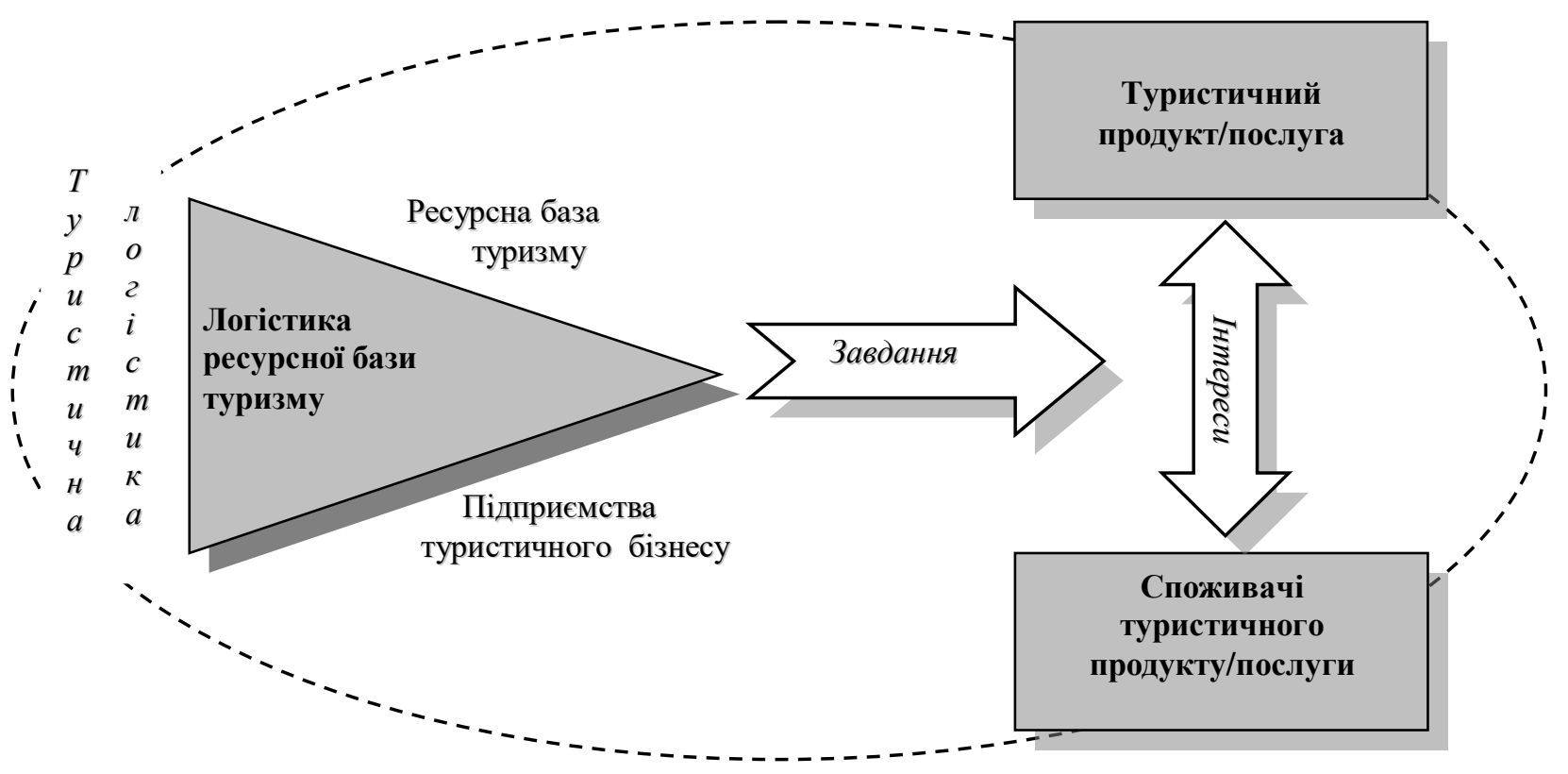

Система управління в туристичному бізнесі

\section{Рис. 1. Місце логістики ресурсної бази у системі управління в туристичному бізнесі [авторська розробка]}

Туристичний інтерес проявляє себе через бажання людини реалізувати ним: отриману соціальноекономічну, культурно-політичну, освітньо-наукову, геопросторову, природно-кліматичну інформацію; потребу в певних емоціях або перспективу покращення фізичного здоров’я за допомогою туристичної послуги, товару й продукту, заснованих на комплексі туристичних ресурсів.

Об'єкти туристичного інтересу - визначні пам'ятки історії, природні об'єкти і природнокліматичні зони, соціально-культурні об'єкти, бізнес, наукові, event-заходи та політичні події тощо спроможні задовольнити бажання й потреби туриста під час туристичної поїздки або подорожі й споживанні туристичних послуг або продукту. Для результативного використання об'єктів туристичного інтересу в туристичному бізнесі потрібне певне забезпечення [18]:

- надання туристичної інформації про конкретний туристичний об'єкт, необхідної й достатньої для вибору подорожі саме у цю місцевість і до цього об' єкта; 
- комфортне і безпечне переміщення туриста до цієї місцевості;

- розміщення;

- харчування;

- розваги (анімаційні послуги).

Таким чином, логістика ресурсної бази $є$ компонентом системи управління в туристичному бізнесі, що містить функціональні області, які вирішують певні завдання:

1) визначення сутності та встановлення значення ресурсної бази в туризмі; 3 довкіллям;

2) раціонального використання туристичних ресурсів та керування процесом взаємодії туриста

3) дослідження логістичного потенціалу рекреаційно-туристичних ресурсів та науковометодична реалізація логістичного підходу до управління соціально-економічними (інфраструктурними) ресурсами туризму.

Отже, логістична оцінка рекреаційно-туристичних ресурсів базується на визначенні їх логістичного потенціалу, тобто максимально можливої для даного туристичного ресурсу кількості споживачів (потік туристів), що [14]:

- не зашкодить стану самих ресурсів;

- не зашкодить самопочуттю та стану здоров'я туристів;

- не зашкодить екології місця знаходження ресурсу;

- не порушить «показник гостинності» (припустиме співвідношення числа туристів та постійних мешканців, за якого зберігається атмосфера гостинності; оптимальним вважається співвідношення не вище 1:3);

- не зашкодить безпеці туристів.

Що стосується методики визначення логістичного потенціалу ресурсної бази туризму, то в сучасній науковій літературі існує чотири підходи $[8 ; 9 ; 10 ; 16]$ :

1) рекреалогічний;

2) порогового аналізу;

3) кількісних характеристик;

4) рекреагеографічний.

Відповідно, науково-методична реалізація логістичного підходу до управління соціальноекономічними (інфраструктурними) ресурсами туризму є предметом подальшого поглибленого вивчення і входить до наукової сфери інтересів авторів даної праці.

Реалізацію вище описаних частин третього завдання логістики ресурсної бази туризму слід здійснювати з урахуванням їхньої класифікації, що входить до першочергового завдання і вимагає, від початку, встановити сутність і значення туристичних ресурсів. Так, під туристичними ресурсами слід розуміти об’єкти і специфічні особливості навколишнього середовища (артефакти природного або антропогенного походження), які володіють певною рекреаційно-туристичною цінністю, виступають предметом інтересу туристів і можуть бути використані з метою організації відпочинку, оздоровлення або ж культурного збагачення людей та здатні спонукати до подорожі (споживання туристичного продукту/послуги).

Ступінь освоєння і розвитку туристичних ресурсів на тій чи іншій території визначається їх властивостями [5]:

- атрактивність (привабливість) ресурсу;

- доступність (в першу чергу - транспортна);

- наукова, культурна та екскурсійна значимість;

- потенційний запас (ємність) ресурсу;

- пейзажні і екологічні характеристики;

- способи та інтенсивність використання ресурсу.

На нашу думку, класифікація туристичних ресурсів, запропонована польським економістом М.Труасі в 1963 році, не дивлячись на ії просту структуру, повністю відображає склад ресурсної бази туризму.

Отже ресурсна база туризму містить три категорії ресурсів:

1) Природні або рекреаційні туристичні ресурси (бальнеологічні, кліматичні, ландшафтні, пляжні, заповідні території, пам'ятники природи тощо);

2) Історико-культурні ресурси (архітектурні споруди, палацові ансамблі, фортеці, музеї, скульптурні пам'ятники, історичні некрополі, твори мистецтва та інше);

3) Соціально-економічні або інфраструктурні ресурси (готелі, кафе і ресторани, екскурсійні бюро, кемпінги, санаторії, розважальні комплекси транспортні та авіаційні компанії тощо).

Крім того, вище зазначені категорії ресурсів можна виділити у два класи: 
I клас: Прямі (безпосередні) - це природні та історико-культурні об'єкти, що безпосередньо використовуються в організації видів туристичної діяльності (пізнавальний, діловий, рекреаційний, екологічний, event-туризм).

II клас: Непрямі (додаткові) - інфраструктурні або просторові (об’єкти розміщення - турбази, готельне господарство, кемпінги, бази відпочинку, пансіонати, санаторії; об’єкти харчування - кафе, ресторани, їдальні, бари; об’єкти обслуговування туристичних потреб - шляхи сполучення, транспорт і дорожнє господарство, торгівля, побутове обслуговування, сучасні інформаційні та рекламні служби, туристичні фірми, навчальні заклади, підприємства з виробництва товарів туристичного сервісу тощо), матеріальні, фінансові, трудові та інформаційні ресурси, які залучаються з метою освоєння прямих туристських ресурсів.

Далі ми більш детально розглянемо раціональне використання ресурсної бази туризму, з точки зору екологізації, валеології і курортології, за допомогою основних і найбільш затребуваних рекреаційних туристичних ресурсів, а саме: бальнеологічних, кліматичних, ландшафтних, пляжних; історико-культурних, розважально-подієвих та соціально-економічних.

Під раціональним використанням слід розуміти не тільки економічно обгрунтоване використання туристичних ресурсів, а також:

1) щадне використання у сенсі екологічного усвідомлення як з боку туристичного бізнесу, так і споживача туристичного продукту/послуги;

2) розумне використання у лікувальному, оздоровчому, профілактичному, пізнавальному, освітньому, розважальному, діловому значенні з боку туриста в ролі споживача ресурсу при задоволенні власного інтересу;

3) доцільне використання у лікувальному, оздоровчому, профілактичному, пізнавальному, освітньому, розважальному, діловому значенні туристичним бізнесом при формуванні туристичного продукту/послуги.

Екологізація у туризмі є науково-обгрунтованою діяльністю людини, суть якої полягає в раціональному використанні його ресурсної бази та управлінні процесом взаємодії, як споживача туристичних ресурсів - туриста, так і всього суспільства з довкіллям.

Екологізацію як одне із завдань логістики ресурсної бази у туристичному бізнесі треба розглядати у наступних суб’єктних категоріях (рис. 2):

- екологізація економічних процесів;

- екологізація споживчої поведінки;

- екологізація суспільного усвідомлення;

- екологізація взаємодії галузей;

- екологізація відповідальності підприємства.

Спираючись на концепцію сталого розвитку яка задекларована Конференцією ООН у Ріо-деЖанейро і широко обговорювалася на 19-й спеціальній сесії Генеральної Асамблеї ООН у 1997 р. у НьюЙорку [17] та виділені вище суб’єктивні категорії екологізації в туристичному бізнесі можна виділити наступні екологічні детермінанти, стійкі до розвитку будь -якої економічної системи в умовах сучасної світогосподарської будови:

1. Забезпечення гармонійного розвитку людського суспільства та навколишньої природного середовища у процесі формування ноосфери (сфери взаємодії суспільства та природи, у границях якої розумна людська діяльність залежить від визначального фактору розвитку у певний період діяльності); 


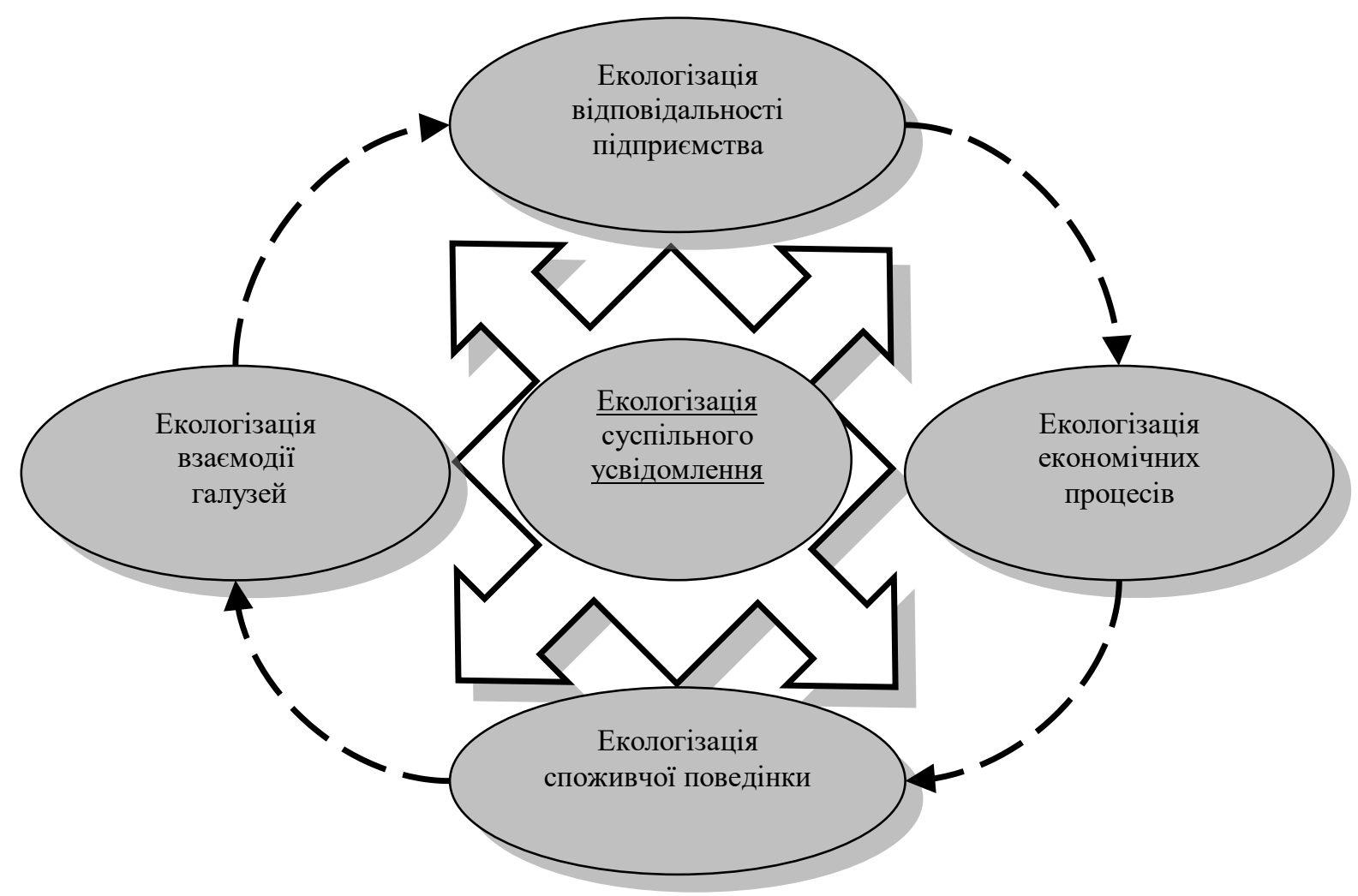

Рис. 2 Суб̆'єктивні категорії екологічного усвідомлення в значенні раціонального використання ресурсної бази туризму

[авторська розробка]

2. Перехід до енергетики альтернативних джерел;

3. Максимізація можливостей використання безвідходних та маловідходних виробництв різної функціональної спрямованості 3 застосовуванням високоефективного технологічного механізму замкнутого циклу;

бізнесу;

4. Використання біотехнології у виробничих процесах в суміжних галузях туристичного

5. Об'єктивна необхідність посилення контролю та моніторингу структур та чисельності популяцій представників світової та місцевої флори та фауни;

6. Розширення практики застосування методики результативного використання ресурсної бази в туристичному бізнесі.

Екологізація туристичної детстинації буде залежати від ряду факторів:

- контрольованої і регульованої (з боку підприємств туристичного бізнесу) та відповідальної (з боку споживачів туристичного продукту/послуги) організації туристичної діяльності;

- планування розвитку та модернізації туристичної інфраструктури відповідно до загальноприйнятих міжнародних стандартів якості та екологічного усвідомлення раціонального використання ресурсної бази туризму;

- логістичної концепції управління в туристичному бізнесі з визначенням пріоритетів вибору потенційних споживачів туристичної продукції/послуг та факторів сезонності;

- рівня знань туристів з екологізації туристичної діяльності та усвідомленого рекреаційного ресурсокористування.

Окремим напрямком екологічного усвідомлення раціонального використання ресурсної бази туризму треба виділити контрольоване, регульоване та відповідальне ставлення до не відновлюваних ресурсів та використання відновлюваних в організації господарської діяльності готелів і ресторанів. Крім цього усвідомлення місця особистості на планеті та власного впливу на навколишнє середовище, що виражається у попиті на екологічно чисті послуги, тому підприємства гостинності i ресторанного господарств повинні враховувати екологічні потреби населення у своїй діяльності.

Основними джерелами забруднення довкілля $є$ каналізаційні стоки та побутові відходи, недосконалі системи опалення, надмірна забудова, витоптування, неорганізований відпочинок поблизу закладів розміщення та харчування, стихійна розбудова нічліжної бази у приватному секторі, надмірна кількість відвідувачів. Це все впливає на довкілля і веде до забруднення води, повітря, зменшення 
водних ресурсів, розбалансування клімату, зміни структури грунтів, збільшення їх щільності, візуального забруднення, погіршення естетичної цінності. Екологізація готельно-ресторанного бізнесу повинна стосуватись абсолютно всіх його сфер.

Сьогодні в міжнародній бізнесовій практиці надзвичайно популярною $є$ концепція екологічних готелів [12]. Метою таких готелів є зменшення негативних явищ між наданням послуг з розміщення та природою та має важливе значення для підвищення конкурентоспроможності готельно-ресторанного бізнесу в Україні. Еко-готелі функціонують за принципом гармонійного сусідства 3 природою, не забруднюючи навколишне середовище продуктами життєдіяльності туристів. Наприклад, деякі готельні підприємства збудовані з біорозкладних матеріалів.

Відповідно до європейських стандартів екологічні готелі повинні задовольняти наступні вимоги:

- наявність системи екологічно чистого опалення;

- мати власні споруди для очищення водостоку;

- розділяти відходи згідно до класифікації;

- використовувати електрику, що виробляється 3 безпечного для довкілля палива (альтернативні джерела - сонячні панелі та «вітряки»);

- для освітлення застосовувати енергозберігаючі лампи;

- для приготування їжі використовувати екопродукти.

Основними напрямками екологізації закладів ресторанного господарства $є$ :

- користування альтернативними джерелами енергії;

- економія тепла, води;

- зменшення обсягів сміття;

- вилучення з ужитку одноразового пластикового посуду;

- екологічність у створенні інтер'єрів закладів;

- інформування відвідувачів про екологічну політику закладів.

Розвиваючи туризм території, об’єкти з особливим екологічним статусом можуть забезпечити істотний внесок у місцеву економіку, сприятимуть залученню до регіону міжнародної уваги та інвестицій, а також створенню нових робочих місць для місцевого населення. Важливо відмітити, що для територій та об'єктів природно-заповідного фонду, де проводиться рекреаційна діяльність, регульований туризм $є$ найбільш оптимальним засобом використання унікальних природних об'єктів в цілях туризму та рекреації. Екологізація має забезпечуватися комплексом дієвих заходів, в тому числі застосування екологічно безпечних технологій в обслуговуванні туристів, а також різноманітних заходів, спрямованих на підвищення рівня екологічної свідомості туристів.

Характерною рисою сучасності є прогресивна нестабільність через глобалізаційні перетворення у соціумі, економічній та технологічній сферах діяльності людини, кліматичні зсуви у бік потепління й екологічні проблеми, тотальна урбанізація, зміна характеру трудової діяльності. Тому є зрозумілим, що усе це суттєво відбивається на особистості, особливо на їі біологічній природі і ставить складні завдання, що впливають на тенденції та напрямки у її суспільному розвитку.

Валеологія, як наука, вивчає теоретичні проблеми формування, зберігання, підтримання та закріплення здоров'я особистості з використанням медичних, нетрадиційних - парамедичних технологій.

Валеологія $є$ комплексною наукою про взаємозв'язок між здоров'ям і визначальними його факторами: соціальних, економічних і психологічних умов життєдіяльності особистості; профілактиці індивідуального психічного, фізичного, професійного і суспільного здоров'я (в тому числі через туристичний бізнес, різноманіття туристичної діяльності, що пов'язані з ресурсною базою туризму).

Курортологія, як наука, вивчає лікувальні властивості та характер дії на організм людини рекреаційних туристичних ресурсів, можливості їх застосування з лікувальною і профілактичною метою на курортах і поза їх межами.

Курортологія, у теоретичному полі наукового пізнання, використовує досягнення і методи загальної кліматології і гідрогеології; фізіології, гігієни медицини. До практичних завдань курортології входять: пошук і дослідження курортних ресурсів; вивчення потреб населення в санітарно-курортному лікуванні і розробка наукових основ його організації; розробка рекомендацій для санаторно-курортного лікування й методи застосування курортних рекреаційних ресурсів при різних захворюваннях; розробка принципів і нормативів курортного будівництва і благоустрою, включаючи питання санітарної охорони курортів.

Тобто, у теоретичному плані метою i валеології, i курортології як науки $є$ вивчення закономірностей формування здоров'я особистості і розробка методів моделювання «здорового стилю життя», а у практичному - має реалізувати мету, спрямовану на збереження, зміцнення і розвиток психофізичного здоров'я, що є підгрунтям до креативного усвідомлення себе у природі та суспільстві за допомогою рекреаційних туристичних ресурсів, зокрема, та туристичної бази туризму, в цілому. Таким чином, валеологія і курортологія оперують двома антагонічними і водночас тісно сплетеними поняттями як [6]: 
1) Здоров’я - абстрактно-логічна категорія, яка може бути описана різними модельними характеристиками;

2) Хвороба - це патологічний процес пов'язаний з втратою індивідом активної самостійності у реалізації власної життєвої установки, втратою оптимального зв'язку із навколишнім середовищем і соціумом.

Обидві категорії визначають соціально-детермінований стан особистості і мають чітку основу: біологічну і соціальну, оскільки усі свої потреби вона реалізує через функції фізіологічних систем і все соціальне реалізується через біологічне.

Однак, справедливим буде твердження, що не існує абсолютного здоров’я, яке, за своєю суттю, є динамічним станом організму і завжди буде існувати небезпека розвитку хвороби в наслідок переходу кількісних змін (біологічних) у якісні (соціальні).

Сутність поняття «здоров'я» і до тепер є предметом наукових досліджень у практиці і теорії медицини, фізичної культури, реабілітаційної справи, валеології і курортології, розглядаючи його через призму таких понять як:

- фізичне, душевне, сексуальне, соціальне благополуччя, здатність пристосовуватись до умов зовнішнього і внутрішнього середовища та природного процесу старіння, відсутність фізичних дефектів;

- свобода особистості оптимально задовольняти власні матеріальні і духовні потреби;

- безпека, надійність, захист, належність до суспільства, наявність поваги, самоповаги, свободи, що забезпечить повний розвиток власних талантів особистості;

- валеологічний процес формування організму і особистості.

Отже, можна стверджувати, що здоров'я формується за рахунок двох тісно сплетених i взаємопроникнених, але якісно різних сфер існування особистості (рис. 3 (б)): I) розумового благополуччя, як прояву вищого порядку психіки та II) адаптації біологічного організму до оточуючого середовища за для виживання. В свою чергу, наслідком творчої цивілізованої діяльності людини є 90\% всіх сучасних факторів ризику існуючих і майбутніх хвороб людства, а також загроза в цілому екологічному благополуччю природного середовища, а відтак 90\% адаптивних процесів особистості до оточуючого середовища. Сфери існування відповідають сферам пізнання, відповідно: креативних процесів пов'язаних з досягненням вищих цінностей (активне творення історії, нові форми соціального і економічного укладу) та адаптивних процесів пов'язаних з повноцінним життям в суспільстві.

Амосов М. М. розглядав здоров’я, саме, як динамічний стан організму, увів поняття «кількість здоров'я». Погоджуємося 3 думкою ученого, що для поширення еталонів здоров'я (здорового стилю життя) у суспільстві, потрібні дві умови: необхідність і мода [1; 2], що виражені в сучасних тенденціях організації світогосподарських відносин у ланцюгу «людина-природа-суспільство-людина».

Щоб дослідити детермінанти формування «здорового стилю життя», потрібно знати феномен людини, рівні ії організації.

Відтак, людина-особистість є системою з пірамідальним принципом будови, яка має чотири рівні існування що відповідають станам пізнання за сферами існування та сферами пізнання (рис. 3 (а;б)):

1- Нижній, соматичний - тілесний стан;

2- Середній, психічний - душевний стан;

3- Верхній, духовний - духовний стан;

4-Надсвідомість - ірраціональний творчий стан. 


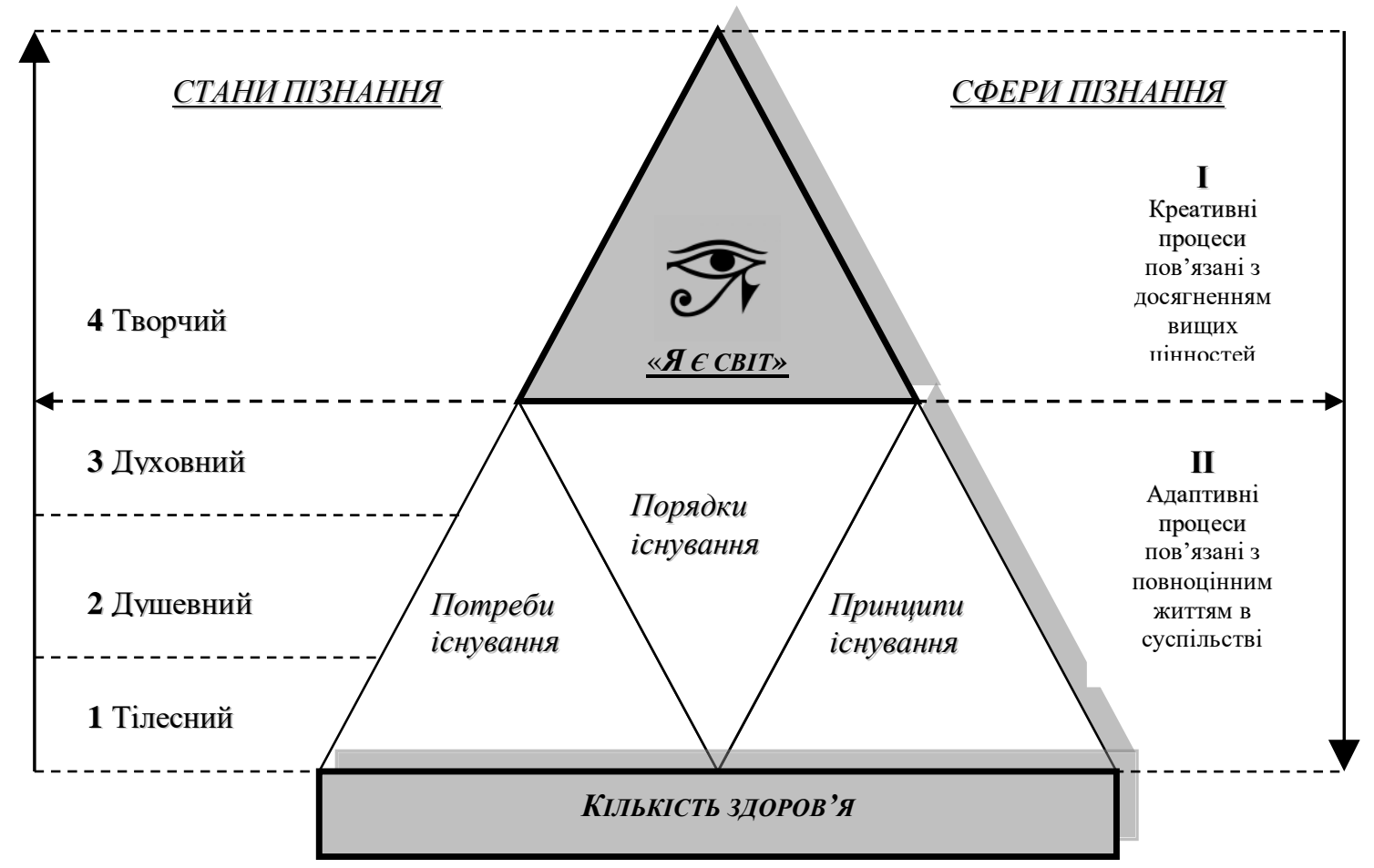

а) Суб'єктивна система життєздатності - «Піраміда особистості»

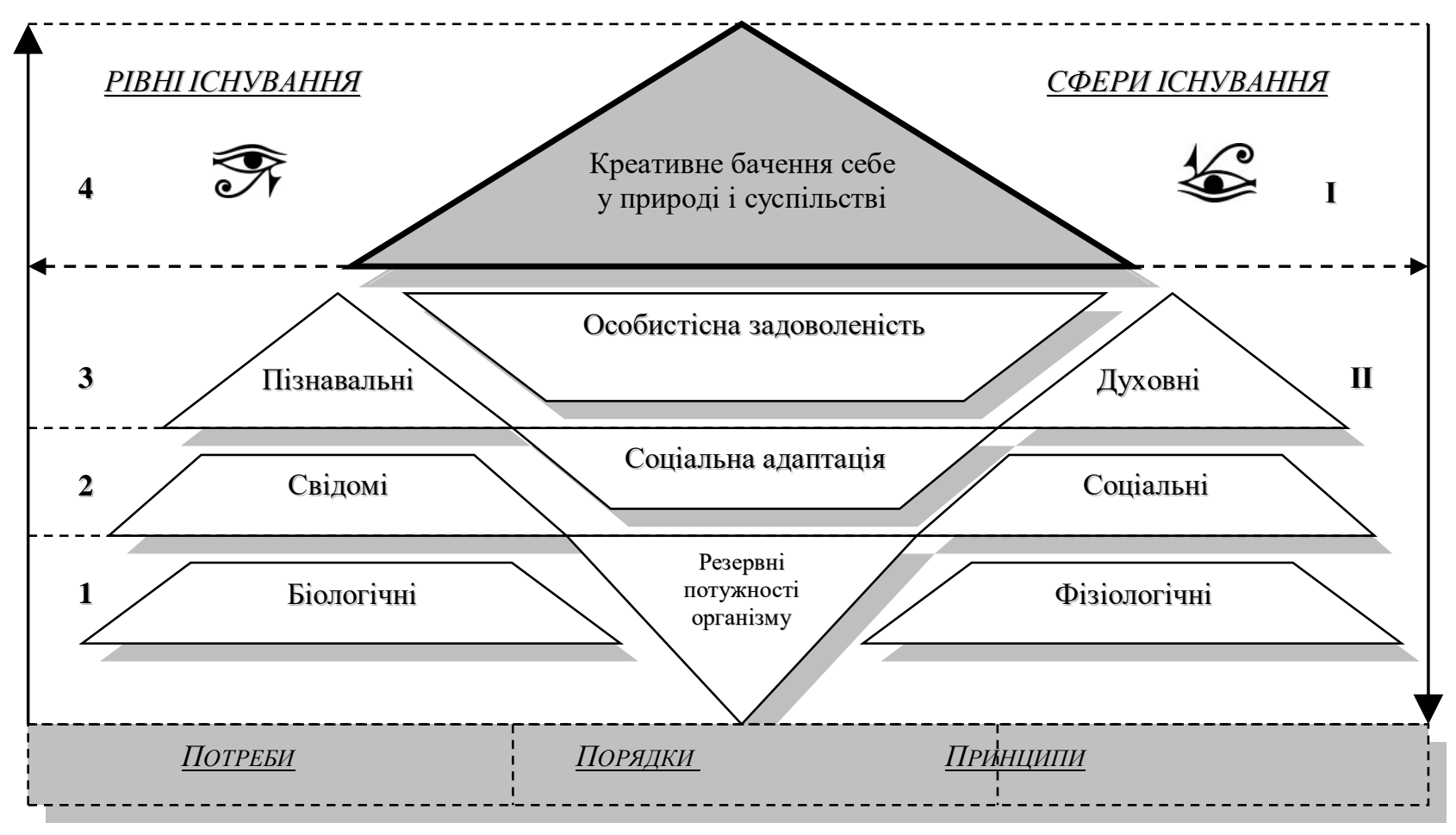

б) Детермінанти формування «здорового стилю життя»

Рис. 3. Детермінанти формування «здорового стилю життя» у суб'сктивній системі життєздатності - «Піраміда особистості»

[авторська розробка] 
Факторами, що впливають на особистість: вроджені біологічні можливості, соціальне середовище прибування (сім`, робочий колектив, друзі), природно-кліматичні умови (ресурсні, екологічні особливості регіону проживання), що в свою чергу формують певні атрибути життя (економічний рівень життя, соціальну якість життя, соціально-психологічний стиль життя, соціальноекономічний уклад життя). Збалансованість особистості з навколишнім світом передбачає організоване поєднання умов та можливостей життя, як природних, так і соціальних, це насамперед іiі комфортне відчуття себе в ньому.

Структуроутворюючим фактором кожної системи, в тому числі і суб’єктивної системи життєздатності - «Піраміда особистості» (рис.3 (а)), є кінцевий результат, ціль функціонування системи. Можна виділити чотири базові цілі життя:

1) виживання (у соматичному стані), тобто формування й зберігання своєї індивідуальної біологічної структури, збереження популяції;

2) адаптація особистості до оточуючого середовища (на психічному рівні), тобто потреба прожити повноцінне життя в суспільстві;

3) реалізація себе та розвиток альтруїзму, прагнення зрозуміти себе і Світ, себе у Світі, прожити життя у згоді зі своїми індивідуальними прагненнями, здібностями (на духовному рівні);

4) проявити себе творцем «Я є Світ» (на рівні надсвідомості - стані розумового благополуччя пов'язаного з досягненням вищих цінностей.

Так, безперервність обміну із зовнішнім середовищем забезпечує динамічну збалансованість суб'єктивної системи життєздатності особистості - їі збереження і розвиток в часі, а порушення цього процесу в динаміці викликає захворювання.

У рішенні валеологічних та курортологічних завдань, з точки зору «необхідності» - формування «здорового стилю життя», мова йде про пробудження внутрішніх резервних потужностей організму особистості як споживача рекреаційних туристичних ресурсів, його успішної соціальної адаптації, особистісної задоволеності через усвідомлене ставлення до себе та оточуючого середовища, що $є$ виявам узгодженості «Піраміди особистості» та виражається у чотирьох станах пізнання.

Для того щоб вирішувалася проблема формування «здорового стилю життя», 3 точки зору «моди», необхідно виховання відповідної особистісної культури: фізичної та фізіологічної - управління рухом і процесами в тілі; психологічної та емоційної - управління своїми відчуттями і внутрішнім станом; інтелектуальної та творчої - управління думкою і роздумами, прагненнями. Тому, з точки зору туристичної валеології та курортології базові цілі життя можна співвіднести 3 видами та формами рекреаційної туристичної анімації і рекреаційними туристичними ресурсами (ї призначенням у туристичному бізнесі і особливостями їх використання на курортах у лікувальних, оздоровчих, профілактичних і релаксаційних (духовне оздоровлення) цілях), що сприяють його формуванню та розвитку «кількості здоров’я» (табл. 1).

Якщо перевести ціль і завдання валеології і курортології в площину туризму, то можна зробити висновок, що туризм, з цієї позиції, є сферою життя суспільства, яка створює «модні» тенденції та умови не просто для ведення людиною «здорового способу життя», а до особистісного росту і формуванню «здорового стилю життя»: активно створювати власне здоров'я і відповідати за нього, розкривати власний внутрішній потенціал через реалізацію четвертого рівня особистості - креативну складову.

Під «здоровим стилем життя» слід розуміти - усвідомлену узгодженість цільових життєвих настанов особистості, що керуються вищим - творчим проявом власної свідомості, який проявляється через «кількість здоров’я» і забезпечує динамічну збалансованість їі системи життєздатності.

Виділені наступні критерії «здорового стилю життя» [3]:

- організаційний (наявність повноцінної життєвої стратегії, а не короткочасних тактик виживання; пролонгована регуляція часу; сприйняття життя в єдності їі минулого, сьогодення і майбутнього);

- гігієнічний (раціональний режим праці і відпочинку, оптимальний руховий режим, дотримання правил особистої гігієни);

- комунікативно-діяльнісний (багата палітра різних видів діяльності, регулярна оздоровча діяльність, здатність до продуктивного спілкування, пошуково-творча активність);

- адаптаційно-рольової (гармонійне протікання процесів соціалізації та індивідуалізації, гнучкість в поведінці і спілкуванні);

- культурно-естетичний (широта культурних контактів, наявність естетичного ідеалу, здатність протистояти проявам антикультури, розумне слідування моді);

- ціннісно-мотиваційний (пріоритет цінностей здоров'я і саморозвитку, наявність валеологічного ідеалу);

- емоційно-вольової (емоційно-психологічна стійкість, оптимізм); 
- індивідуально-особистісний (високий рівень самоприйняття і самоповаги, сензитивність до себе, здатність зберігати свою унікальність і творчо реалізовувати іiі).

На підставі даного висновку можна сформулювати концепцію валеотуризму - формування «здорового стилю життя», а саме: зміна вектора уваги від простого споживання туристичних ресурсів на створення особистісного образу «Я є Світ» - «Піраміди особистості» через: побудову гармонійних відносин між людьми, культурами, народами; розширення меж світогляду, світосприйняття; екологізацію свідомості. І тоді туристичні ресурси стають інструментом освіти і формування «кількості здоров'я» людини.

Таблиця 1

Умови та фактори формування «здорового стилю життя» як поведінки споживача рекреаційних

\begin{tabular}{|c|c|c|c|}
\hline \multicolumn{4}{|c|}{ туристичних ресурсів* } \\
\hline $\begin{array}{l}\text { Цілі життя } \\
\text { (рівні } \\
\text { існування) }\end{array}$ & $\begin{array}{c}\text { Види та форми } \\
\text { рекреаційної туристичної } \\
\text { анімації } \\
\end{array}$ & $\begin{array}{c}\text { Рекреаційні туристичні } \\
\text { ресурси }\end{array}$ & $\begin{array}{c}\text { Розумне та доцільне } \\
\text { використання рекреаційних } \\
\text { туристичних ресурсів }\end{array}$ \\
\hline 1 & 2 & 3 & 4 \\
\hline $\begin{array}{c}\text { Виживання } \\
\text { (соматичний } \\
\text { рівень) }\end{array}$ & $\begin{array}{l}\text { - увесь спектр культурно- } \\
\text { розважальних і спортивних } \\
\text { програм у межах } \\
\text { рекреаційної системи } \\
\text { (курорту); } \\
\text { - заплановані } \\
\text { організаторами пригоди, } \\
\text { масштабні ігрові дії з } \\
\text { елементами екстриму, } \\
\text { вболівальницькі активізації }\end{array}$ & $\begin{array}{l}\text { - кліматичні умови, } \\
\text { біорізноманіття, рівнинні } \\
\text { та гірські рекреаційні } \\
\text { ландшафти, річкові та } \\
\text { морські пляжі, мінеральні } \\
\text { води, лікувальні грязі; } \\
\text { - санаторно-курортні } \\
\text { (оздоровчі) заклади }\end{array}$ & $\begin{array}{l}\text { - медична кліматотерапія; } \\
\text { - бальнеотерапія та } \\
\text { бальнеотехніка; } \\
\text {-грязелікування; } \\
\text { - фізіотерапія та } \\
\text { реабілітаційна фізкультура; } \\
\text { - дієтотерапія; } \\
\text { - лікувальний масаж }\end{array}$ \\
\hline $\begin{array}{c}\text { Адаптація } \\
\text { (психічний } \\
\text { рівень) }\end{array}$ & $\begin{array}{l}\text { - вечірні індивідуальні } \\
\text { або дрібно-групові } \\
\text { тематичні, культурно- } \\
\text { пізнавальні програми в } \\
\text { межах готелю або } \\
\text { курортної зони; } \\
\text { - анімація в етноцентрах, } \\
\text { етномузеях, етноготелях; } \\
\text { - фестивалі, народні свята } \\
\text { пізнавально-ігрові, } \\
\text { комунікативні та } \\
\text { екопрограми; } \\
\text { - виставкова анімація } \\
\text { експозицій та зооанімація }\end{array}$ & $\begin{array}{l}\text { - } \text { кліматичні умови, } \\
\text { біорізноманіття, рівнинні } \\
\text { та гірські рекреаційні } \\
\text { ландшафти; } \\
\text { - санаторно-курортні } \\
\text { (оздоровчі) заклади; } \\
\text { - підприємства } \\
\text { гостинності; } \\
\text { - музеї, виставкові } \\
\text { центри; } \\
\text { - пам’ятки історії, } \\
\text { культури, мистецтва, } \\
\text { - знакові події в історії } \\
\text { певної території (політичні, } \\
\text { військові, культурні, } \\
\text { економічні та екологічні } \\
\text { події) }\end{array}$ & $\begin{array}{l}\text { - релаксаційна } \\
\text { кліматотерапія, } \\
\text { - фізіотерапія, } \\
\text { - дієтотерапія: } \\
\text { - психотерапія та ігрова } \\
\text { терапія; } \\
\text { - оздоровчій та } \\
\text { релаксаційний масаж; } \\
\text {-термотерапія; } \\
\text { - зоотерапія } \\
\text { - аквамедитація; } \\
\text { - стоун терапія; } \\
\text { - процедури догляду за } \\
\text { тілом і обличчям }\end{array}$ \\
\hline $\begin{array}{c}\text { Само- } \\
\text { реалізація } \\
\text { (духовний } \\
\text { рівень) }\end{array}$ & $\begin{array}{l}\text { - карнавали, свята, } \\
\text { фестивалі, конкурси, } \\
\text { концерти; } \\
\text { - релігійні свята, } \\
\text { фестивалі і концерти } \\
\text { духовної музики, ри- } \\
\text { туально-обрядові дійства; } \\
\text { - культурно-історичні } \\
\text { реконструкції; } \\
\text { - наукові та ділові ігри; } \\
\text { - спортивні ігри та } \\
\text { змагання; } \\
\text { - обрядова анімація; } \\
\text { - споглядання небесних } \\
\text { тіл }\end{array}$ & $\begin{array}{l}\text { - природні умови та } \\
\text { фактори } \\
\text { - підприємства } \\
\text { гостинності; } \\
\text { - знакові події в історії, } \\
\text { культурі, релігії, } \\
\text { мистецтві певної території } \\
\text { (політичні, військові, } \\
\text { культурно-історичні, } \\
\text { економічні, спортивні та } \\
\text { екологічні події); } \\
\text { - астрономічні події } \\
\text { - модні події }\end{array}$ & $\begin{array}{l}\text { - релаксаційна } \\
\text { кліматотерапія; } \\
\text { - харчова терапія } \\
\text { - таласотерапія; } \\
\text { - термотерапія; } \\
\text { - аквамедитація; } \\
\text { - стоун терапія; } \\
\text { - різні техніки та види } \\
\text { масажу; } \\
\text { - процедури догляду за } \\
\text { тілом і обличчям; } \\
\text { - естетична хірургія та } \\
\text { програми схуднення; } \\
\text { - реалізація хобі (катання } \\
\text { верхи, гра в теніс, гольф, } \\
\text { футбол, серфінг) }\end{array}$ \\
\hline
\end{tabular}


Продовження табл. 1

\begin{tabular}{|c|c|c|c|}
\hline 1 & 2 & 3 & 4 \\
\hline $\begin{array}{c}\text { Пошук та } \\
\text { прояв } \\
\text { креативного } \\
\text { джерела в } \\
\text { собі } \\
\text { (творчий } \\
\text { рівень) }\end{array}$ & $\begin{array}{l}\text { - гастрономічні свята, } \\
\text { фестивалі, театралізовані } \\
\text { дегустації, ресторанні } \\
\text { розважальні заходи; } \\
\text { - майстер класи, } \\
\text { - фольклорні музично- } \\
\text { пісенні, танцювальні } \\
\text { програми, вечорниці; } \\
\text { - клуби за інтересами; } \\
\text { - модні покази }\end{array}$ & $\begin{array}{l}\text { - природні умови та } \\
\text { фактори } \\
\text { - підприємства } \\
\text { гостинності; } \\
\text { - наукові та ділові } \\
\text { конференцї; } \\
\text { - знакові події в історії, } \\
\text { культурі, релігії, мистецтві, } \\
\text { моді певної території } \\
\text { (політичні, військові, } \\
\text { культурно-історичні, } \\
\text { економічні, спортивні та } \\
\text { екологічні події) }\end{array}$ & $\begin{array}{l}\text { - релаксаційна } \\
\text { кліматотерапія, } \\
\text { - гурманотерапія та вино } \\
\text { терапія; } \\
\text { - малювання мандал, } \\
\text { пейзажів; } \\
\text { - танцювальні етюди та } \\
\text { виступи на карнавалах; } \\
\text { - демонстрація власного } \\
\text { модного луку; } \\
\text { - приймання участі на } \\
\text { наукових та ділових } \\
\text { конференціях; } \\
\text { - участь у різного роду } \\
\text { спортивних змаганнях }\end{array}$ \\
\hline
\end{tabular}

*Складено на основі [3] та доопрацьовано авторами

Валеотуризм пропонує цілеспрямовані методи формування «кількості здоров'я» і сприяє [4]:

- утворенню позитивного простору, виникненню позитивних емоцій, відчуттів i, як наслідок, бажання створювати радість собі та іншим;

- зниженню рівня напруженості і агресії;

- зниженню страху допустити помилку, покарання;

- появі можливості і бажання висловлювати свої почуття;

- появі стійкого позитивного ставлення до самого себе, людям, природі і світу в цілому.

Валеотуризм справляє позитивний вплив:

- на мотиваційну сферу, прагнення до підвищення рівня знань, умінь, навичок, успішності в обраній професійній діяльності, творчої самореалізації;

- для створення відносин, заснованих на взаєморозумінні, взаємотурботі, взаємоповазі, створює передумови для зміцнення дружби і любові;

- для стійкого духовного розвитку, дає можливість шукати і знаходити сенс життя, будувати своє життя і відносини на основі гуманних, загальнолюдських цінностей.

Валеотуризм є принципово новим напрямком для оздоровлення та поповнення інформацією, справляє позитивний вплив на «кількість здоров'я» людини і його всебічний розвиток. Валеотуризм доступний і унікальний у створенні умов для розвитку людини, формування екологічної усвідомленості, фактора позитивного, активного і відповідального способу життя. Що стосується курортологічної складової, то сьогодні провідні курорти світу прагнуть розвиватися як полі функціональні, багатоцільові тур центри, що спеціалізуються на задоволенні інтересів оздоровчого туризму [13]. Для комплексного розвитку оздоровчого туризму, до якого можноа віднести і валеотуризм, у конкретному регіоні 3 курортним спрямуванням соціально-економічного розвитку, актуальним є поєднання загального інфраструктурного розвитку території та спільних зусиль баз відпочинку, санаторіїв, приватних садиб і господарств, сфери гостинності та сфери обслуговування туризму, місцевих жителів створює резерви для модернізації всієї ресурсної бази туризму.

Підсумовуючи усі вище наведені пункти дослідження слід зазначити наступне:

1) Логістика ресурсної бази туризму сприяє вирішенню проблематики управління в туристичному бізнесі, і не тільки економічно обгрунтованого, а й щадного, доцільного і розумного використання ресурсної бази галузі; дозволяе зменшити ризики погіршення екологічної ситуації, зниження якості туристичного продукту/послуг, загрози здоров'ю та безпеці туристів.

2) Логістика ресурсної бази туризму має служити основою для визначення стратегії сталого розвитку туризму в країні та іiі регіонах та може стати осново утворюючою умовою смарт-спеціалізації території.

3) Україна має всі необхідні фактори для забезпечення високого розвитку екологізації туристичного бізнесу. Вимоги усвідомленого ресурсокористування можливо виконати при максимально можливій організованості туристичної діяльності, що повинна бути контрольованою, регульованою і відповідальною. 
4) Валеологія, курортологія та анімація створюють умови та виступають концентраторами факторів, що сприяють формуванню «здорового стилю життя» - поведінки споживача рекреаційних туристичних ресурсів.

5) Сучасні тенденції світогосподарської будови та розвитку туристичного ринку спрямовує інтереси споживача на новий вид особистісно-реалізаційного виду туризму - валеотуризму як доступного й унікального фактора позитивного, активного і відповідального «здорового стилю життя» у: створенні умов для розвитку людини; формуванні екологічної усвідомленості, креативного бачення себе у природі та суспільстві.

\section{Список використаної літератури}

1. Амосов Н. М. Энциклопедия Амосова. Алгоритм здоровья. Человек и общество / Н. М Амосов. - Донецк : Сталкер, 2002. - 464 с.

2. Апанасенко Г. Л. Медицинская валеология / Г. Л. Апанасенко, Л. А. Попова. - Ростов н/Д : Феникс, 2000. - 248 с.

3. Валеология как теоретическая основа туристической анимации : [Електронний ресурс] Режим доступу : https://infopedia.su/16xb73c.html - Назва з екрану.

4. Валеотуризм и формирование здорового образа жизни : [Електронний ресурс] / сайт Общественной организации «Валеологический центр «Атланта» - Режим доступу : http://atlantavaleo.org.ua/uslugi/turism/ - Назва з екрану.

5. Виды и классификация туристских ресурсов. Туристская индустрия: [Електронний ресурс] - Режим доступу : https://fb.ru/article/461028/turistskie-resursyi---eto-vidyi-i-klassifikatsiya-turistskihresursov-turistskaya-industriya - Назва $з$ екрану.

6. Грибон В.Г. Валеологія: [Електронний ресурс] / В.Г. Грибон - Режим доступу : https://pidru4niki.com/158407208058/meditsina/valeologiya.

7. Григан С.А. Перспективы применения логистического подхода в управлении туристической деятельностью / С.А. Григан // Физическая культура, здравоохранение и образование: материалы всероссийской научно-практической конференции памяти В.С. Пирусского. - Томск, ТГУ, 2009.

8. Гришин И.Ю. Оценка инновационного потенциала бальнеологической курортной территории / И.Ю. Гришин, Р.P. Тимиргалеева // NovaInfo.Ru. 2016. Т. 3. № 47.

9. Данильчук В.Ф., Бовсуновская А.Я., Крапивина Г.А. Математическая модель определения приоритетных для восстановления рекреационных возможностей территорий и объектов // Вісник ДІТБ. - 2004. - № 8. - С. 32-39.

10. Донченко Л.М. Оцінка пляжних ресурсів для рекреаційного використання на прикладі Запорізького Приазов'я / Л.М. Донченко // Географія і сучасність: Зб. наук. пр. НПУ імені М.П. Драгоманова. - Вип. 13. - К.: Вид-во НПУ імені М. П. Драгоманова, 2005. С.129-135.

11. Лукин А.М. Модернизация логистической системы в туристических фирмах / Лукин А.М. // Экономическая наука сегодня: теория и практика : материалы V Междунар. науч.-практ. конф. (Чебоксары, 3 дек. 2016 г.) / редкол.: О. Н. Широков [и др.]. - Чебоксары: ЦНС «Интерактив плюс», 2016.

12. Павлова С.I., Кім Е.О. Екологізація готельного та ресторанного бізнесу: [Електронний pecypc] / С.I. Павлова, Е.О. Кім - Режим доступу : https://conf.ztu.edu.ua/wp-content/uploads/2021/05/21.pr-my-ta-per-vy-roz-ku-tur-mu-s.-4.pdf.

13. Рутинський М. Й. Класифікації та типології курортів / М. Й. Рутинський // Вісник Львівського університету. - Серія географічна. - 2007. - Вип. 34. - С. 236-246.

14. Смирнов І.Г. Логістика ресурсної бази туризму як запорука його сталого розвитку : [Електронний ресурс] / Смирнов I.Г. http://www.rusnauka.com/9._EISN_2007/Economics/21412.doc.htm.

15. Смирнов I.Г. Логістика туризму: комплексний підхід : [Електронний ресурс] / І.Г. Смирнов - Режим доступу : http://www.rusnauka.com/22_NIOBG_2007/Economics/25102.doc.htm.

16. Смирнов І.Г. Логістика туризму: мезорівень (на прикладі регіонів України) / І.Г. Смирнов // Туристично-краєзнавчі дослідження: Зб. наук. пр. - Вип.6. - К., 2005. - С. 414-416.

17. Телюра Н.А. Теоретичні аспекти рекреаційного природокористування : [Електронний pecypc] / Н.А. Телюра - Режим доступу : http://dspace.nbuv.gov.ua/bitstream/handle/123456789/34934/19Teljyra.pdf.

18. Туристичні ресурси. Поняття та сутність : [Електронний ресурс] - Режим доступу : https://pidru4niki.com/15660721/turizm/turistichni_resursi - Назва з екрану.

\section{References}

1. Amosov N. M. Enciklopediya Amosova. Algoritm zdorov'ya. CHelovek i obshchestvo / N. M Amosov. Doneck : Stalker, 2002. 464 p. 
2. Apanasenko G. L. Medicinskaya valeologiya / G. L. Apanasenko, L. A. Popova. Rostov n/D : Feniks, 2000. 248 p.

3. Valeologiya kak teoreticheskaya osnova turisticheskoj animacii : [Elektronnij resurs] - Rezhim dostupu : https://infopedia.su/16xb73c.html - Nazva z ekranu.

4. Valeoturizm i formirovanie zdorovogo obraza zhizni : [Elektronnij resurs] / sajt Obshchestvennoj organizacii «Valeologicheskij centr «Atlanta» - Rezhim dostupu : http://atlantavaleo.org.ua/uslugi/turism/ Nazva z ekranu.

5. Vidy i klassifikaciya turistskih resursov. Turistskaya industriya: [Elektronnij resurs] - Rezhim dostupu: https://fb.ru/article/461028/turistskie-resursyi---eto-vidyi-i-klassifikatsiya-turistskih-resursovturistskaya-industriya - Nazva z ekranu.

6. Gribon V.G. Valeologiya: [Elektronnij resurs] / V.G. Gribon - Rezhim dostupu : https://pidru4niki.com/158407208058/meditsina/valeologiya.

7. Grigan S.A. Perspektivy primeneniya logisticheskogo podhoda v upravlenii turisticheskoj deyatel'nost'yu / S.A. Grigan // Fizicheskaya kul'tura, zdravoohranenie i obrazovanie: materialy vserossijskoj nauchno-prakticheskoj konferencii pamyati V.S. Pirusskogo. Tomsk, TGU, 2009.

8. Grishin I.YU. Ocenka innovacionnogo potenciala bal'neologicheskoj kurortnoj territorii / I.YU. Grishin, R.R. Timirgaleeva // NovaInfo.Ru. 2016. T. 3. № 47.

9. Danil'chuk V.F., Bovsunovskaya A.YA., Krapivina G.A. Matematicheskaya model' opredeleniya prioritetnyh dlya vosstanovleniya rekreacionnyh vozmozhnostej territorij i ob"ektov // Visnik DITB. 2004. № 8. pp. 32-39.

10. Donchenko L.M. Ocinka plyazhnih resursiv dlya rekreacijnogo vikoristannya na prikladi Zaporiz'kogo Priazov'ya / L.M. Donchenko // Geografiya i suchasnist': Zb. nauk. pr. NPU imeni M.P. Dragomanova. - Vip. 13. Kyiv: Vid-vo NPU imeni M. P. Dragomanova, 2005. pp.129-135.

11. Lukin A.M. Modernizaciya logisticheskoj sistemy v turisticheskih firmah / Lukin A.M. // Ekonomicheskaya nauka segodnya: teoriya i praktika : materialy V Mezhdunar. nauch.-prakt. konf. (CHeboksary, 3 dek. 2016 g.) / redkol.: O. N. SHirokov [i dr.]. - CHeboksary: CNS «Interaktiv plyus», 2016.

12. Pavlova S.I., Kim E.O. Ekologizaciya gotel'nogo ta restorannogo biznesu: [Elektronnij resurs] / S.I. Pavlova, E.O. Kim - Rezhim dostupu : https://conf.ztu.edu.ua/wp-content/uploads/2021/05/21.-pr-my-taper-vy-roz-ku-tur-mu-s.-4.pdf.

13. Rutins'kij M. J. Klasifikaciï ta tipologiï kurortiv / M. J. Rutins'kij // Visnik L'vivs'kogo universitetu. - Seriya geografichna. 2007. Vip. 34. pp. 236-246.

14. Smirnov I.G. Logistika resursnoï bazi turizmu yak zaporuka jogo stalogo rozvitku : [Elektronnij resurs] / Smirnov I.G. - Rezhim dostupu : http://www.rusnauka.com/9._EISN_2007/Economics/21412.doc.htm.

15. Smirnov I.G. Logistika turizmu: kompleksnij pidhid : [Elektronnij resurs] / I.G. Smirnov Rezhim dostupu : http://www.rusnauka.com/22_NIOBG_2007/Economics/25102.doc.htm.

16. Smirnov I.G. Logistika turizmu: mezoriven' (na prikladi regioniv Ukraïni) / I.G. Smirnov // Turistichno-kra€znavchi doslidzhennya: Zb. nauk. pr. - Vip.6. - K., 2005. - S. 414-416.

17. Telyura N.A. Teoretichni aspekti rekreacijnogo prirodokoristuvannya : [Elektronnij resurs] / N.A. Telyura - Rezhim dostupu : http://dspace.nbuv.gov.ua/bitstream/handle/123456789/34934/19-Teljyra.pdf.

18. Turistichni resursi. Ponyattya ta sutnist' : [Elektronnij resurs] - Rezhim dostupu : https://pidru4niki.com/15660721/turizm/turistichni_resursi - Nazva z ekranu. 